\title{
Treatment of poultry slaughterhouse wastewater in upflow anaerobic filter under low upflow velocity
}

\author{
${ }^{1^{*}}$ R. Rajakumar; ${ }^{2}$ T. Meenambal; ${ }^{3}$ J.Rajesh Banu; ${ }^{4}$ I. T. Yeom \\ ${ }^{1}$ Engine Division, Hindustan Aeronautics Ltd., Banaglore-560 093, Karnataka, India \\ ${ }^{2}$ Department of Civil Engineering, Government College of Technology, \\ Anna University, Coimbatore-641 013, Tamilnadu, India \\ ${ }^{3}$ Department of Civil Engineering, Anna University, Tirunelveli-627 007, Tamilnadu, India \\ ${ }^{4}$ Department of Civil and Environmental Engineering, SungKyunKwan University, Suwon-Si, South Korea \\ Received 10 August 2010; revised 8 October 2010; accepted 25 November 2010; available online 1 December 2010
}

\begin{abstract}
The wastewater discharged by poultry slaughterhouse industries are characterized mainly by high biochemical oxygen demand, high suspended solids and complex mixture of fats, proteins and fibers requiring systematic treatment prior to disposal. In this study, the performance of an upflow anaerobic filter reactor for treating Indian poultry slaughterhouse wastewater under low upflow velocity of $1.38 \mathrm{~m} /$ day at mesophilic temperature $\left(29-35^{\circ} \mathrm{C}\right)$ was investigated. The reactor was inoculated with anaerobic non-granular sludge from an anaerobic reactor treating the poultry slaughterhouse wastewater. The reactor took 147 days for complete start-up with removal efficiencies of total chemical oxygen demand and soluble chemical oxygen demand of 70 and $79 \%$ respectively. The maximum total chemical oxygen demand removal efficiency of $78 \%$ was achieved at an organic loading rate of $10.05 \mathrm{~kg} / \mathrm{m}^{3} /$ day and at an hydraulic retention time of $12 \mathrm{~h}$. The average methane content varied between 46 and $56 \%$ and methane yield at maximum removal efficiency was $0.24 \mathrm{~m}^{3} \mathrm{CH}_{4} / \mathrm{kg} \mathrm{COD}_{\text {removed }}$ day. Sludge granules of 1-2 mm were observed in between the packing media. Scanning electron microscope analysis revealed that sludge granules are composed of clumps of Methanosarcina clustered with less intertwined Methanosaeta fibre of granules. The lower velocity used in this study has achieved better performance of the reactor by creating active microbial formation with stable $\mathrm{pH}$ upto an organic loading rate of $14.3 \mathrm{~kg} / \mathrm{m}^{3} / \mathrm{day}$. This has proved that the poultry slaughterhouse wastewater can be treated using anaerobic filter reactor under low upflow velocity.
\end{abstract}

Keywords: Granular sludge; Mesophilic temperature; Methane yield; Methanosarcina; Methanosaeta; Scanning Electron Microscope

\section{INTRODUCTION}

Poultry industry is one of the fastest growing segments of the agricultural sector in India today which has undergone a paradigm shift in structure and operation. A significant feature of India's poultry industry has been its transformation from a mere backyard activity into a major commercial activity in aspects of production which ultimately leads to the issues relating to environmental pollution in terms of high biochemical oxygen demand (BOD) and chemical oxygen demand (COD), large amount of total suspended solid (TSS), and various other pollutants (Mehta et al., 2002; Nwuche and Ugoji, 2008; Igwe et al., 2008; Shah et al .,2009). As is typical of many food ॠ *Corresponding Author Email: rrajakumar_78@yahoo.com Tel./Fax: +918022326233 processing industries, poultry processing is characterized by relatively high usage of water, most of it for non-consumptive purposes (Kroyer, 1991; Okoli et al., 2006). The quantity of wastewater discharged from processing operations in a poultry plant may range from 5 to 10 gallons per bird with 7 gallons being a typical value. Poultry processing wastewater is typically organic in character, higher than domestic sewage in BOD, and high with suspended solids and floating material such as scum and grease. Due to the increasing usage of water, the wastewater generation is tremendous and also having high concentration of pollutants fluctuating in wide range. Depending on the degree of treatment required poultry processors have the option of utilizing physical, chemical and 
biological treatment systems. Each system type possesses unique treatment advantages and operational difficulties.Among the different treatment systems, high rate anaerobic reactors have been proposed as good alternative and effective system because of its numerous advantages like low initial and operational costs, smaller space requirements, high organic removal efficiency and low sludge production, combined with a net energy benefit through the production of biogas (Banu et al., 2007; Behera et al., 2007; Juang and Chiou, 2007; Liu et al., 2010; Bicheldey and Latushkia, 2010; Karapidakis et al., 2010). Anaerobic filters (AF) are considered as most useful system, at high organic loading rates (OLR) for treatment of low and high strength wastewaters (Tay and Show, 1998) due to the availability of large biomass and consistent performance (Jawed and Tare, 1997). Guerrero et al., (1997) observed 80-90 \% of treatment efficiencies at an OLR of 1.62 to $5.26 \mathrm{~kg} / \mathrm{m}^{3} /$ day and HRT of 4.41-12.22 days for the treatment of fish meal processing wastewater using PVC media. Tritt (1992) conducted the slaughterhouse wastewater treatment using two fixed-bed reactors with two different media at OLR of $2-18.5 \mathrm{~kg} / \mathrm{m}^{3} /$ day and HRT (Hydraulic Retention Time) of 5 to 0.5 day. The COD removal efficiencies of 85-30\% (bamboo as carrier) and 80-27 $\%$ (bones as carrier) were achieved. Del pozo et al., (2000) studied the application of fixed film reactor for a treatment of poultry slaughterhouse wastewater and attained the COD removal efficiencies ranging from 85 to $95 \%$ at an OLR of $8 \mathrm{~kg} / \mathrm{m}^{3} /$ day. However, it was observed at high OLR (35 kg/m³/day) led to lower removal efficiencies of 55-75 \%. Borja and Banks (1995) studied the performance comparison of AF with fluidized bed reactor (FBR) for the treatment of Palm Oil Mill effluent and achieved the maximum OLR of 20 $\mathrm{kg} / \mathrm{m}^{3} /$ day for AF without clogging. Ruiz et al., (1997) evaluated the performance of upflow anaerobic sludge blanket (UASB) with AF reactor and found lower removal efficiencies were observed in AF at high OLR compared with UASB. The existence of biomass in anaerobic filters was both as attached film and suspended flocs/granules. Jawed and Tare (2000) observed that the deposition of sludge solids in the packing media was uneven in the downflow anaerobic filter (DAF) as compared to that in upflow anaerobic filter (UAF). Apart from attached microbial film, granular sludge also plays a major role in treatment of anaerobic filters. Granules were observed in anaerobic filters, and the formation of granules is the result of microbial and hydraulic selection pressure. Microbial selection depends on substrate concentration, substrate type and various environmental factors (Hulshoff Pol et al., 1983; Grotenhuis et al., 1991; Tay and Yan, 1996). Hydraulic selection involves the physical separation of dispersed microorganisms using shear forces and differences in mixing characteristics (Hulshoff pol et al., 1983). The upflow velocity is one of the main factors affecting the efficiency of upflow reactors. Thirumurthi, (1988) observed poor reactor performance at liquid velocities below $16 \mathrm{~m} / \mathrm{d}$ due to inadequate mixing of the sludge bed and poor substrate/biomass contact in the anaerobic filter. Also the performance was deteriorated during operation at upflow velocities above $163 \mathrm{~m} / \mathrm{d}$ due to excessive biomass shear and loss in the effluent. Upflow velocities as 0.25 to $0.8 \mathrm{~m} /$ $\mathrm{h}$ are favourable for granule growth and accumulation in upflow anaerobic sludge blanket reactors (Ghangrekar et al., 2003). In the present study the upflow velocity was low $(1.38 \mathrm{~m} / \mathrm{d})$ as compared to the previous studies. Studies have been carried out for the treatment of different slaughterhouse wastewater using several anaerobic treatment systems. The flow and characteristics of each slaughterhouse wastewater depends on size and type of animals slaughtered. Hence one slaughterhouse wastewater cannot be compared with the other slaughterhouse wastewater. No study has been carried out specifically for Indian poultry slaughterhouse wastewater by AF using pleated Poly Vinyl Chloride (PVC) rings as packing media. Keeping the above mentioned point in mind, treatment of Indian poultry slaughterhouse wastewater using AF reactor was investigated under low upflow velocity in the present study. This study was conducted at different organic loading rates by analyzing the monitoring parameters total COD (TCOD), soluble COD (SCOD), $\mathrm{pH}$, VFA, alkalinity, bio gas production and optimum OLR was determined. SEM analysis was performed to identify the microbial population in the reactor. The research work was carried out at Environmental Engineering laboratory in the Department of Civil Engineering, Government College of Technology, Coimbatore during 2008.

\section{MATERIALS ANDMETHODS}

Experimental set -up

Bench scale continuous Upflow Anaerobic Filter (UAF) reactor made of polyvinyl chloride (PVC) was 
used in the present study. The reactor had an internal diameter of $10 \mathrm{~cm}$ and total height of $82 \mathrm{~cm}$ resulting in total volume of $6.4 \mathrm{~L}$ and working volume of $5.4 \mathrm{~L}$ with a gas head space of $1 \mathrm{~L}$. The reactor was packed with packing media of about $4 \mathrm{~L}$. The reactors were fed with substrate using peristaltic pump (Model: PP-20, Miclins). The peristaltic pump can maintain constant flow rate in the range of $2 \mathrm{~mL} / \mathrm{h}$ to $10 \mathrm{~L} / \mathrm{h}$, available with timer and LED display for flow rate of function and time. The effluent pipe was connected to a water seal arrangement to prevent escape of the gas through the effluent. The configuration and the system layout are depicted in Fig. 1. Five sampling ports were installed along the length of each reactor at $11 \mathrm{~cm}$ intervals, starting from a height of $5 \mathrm{~cm}$ above the reactor bottom. Biogas produced from the reactor was collected by water displacement method using Mariotte bottle. The operating temperature of the reactors was in the mesophilic range $\left(29-35^{\circ} \mathrm{C}\right)$.

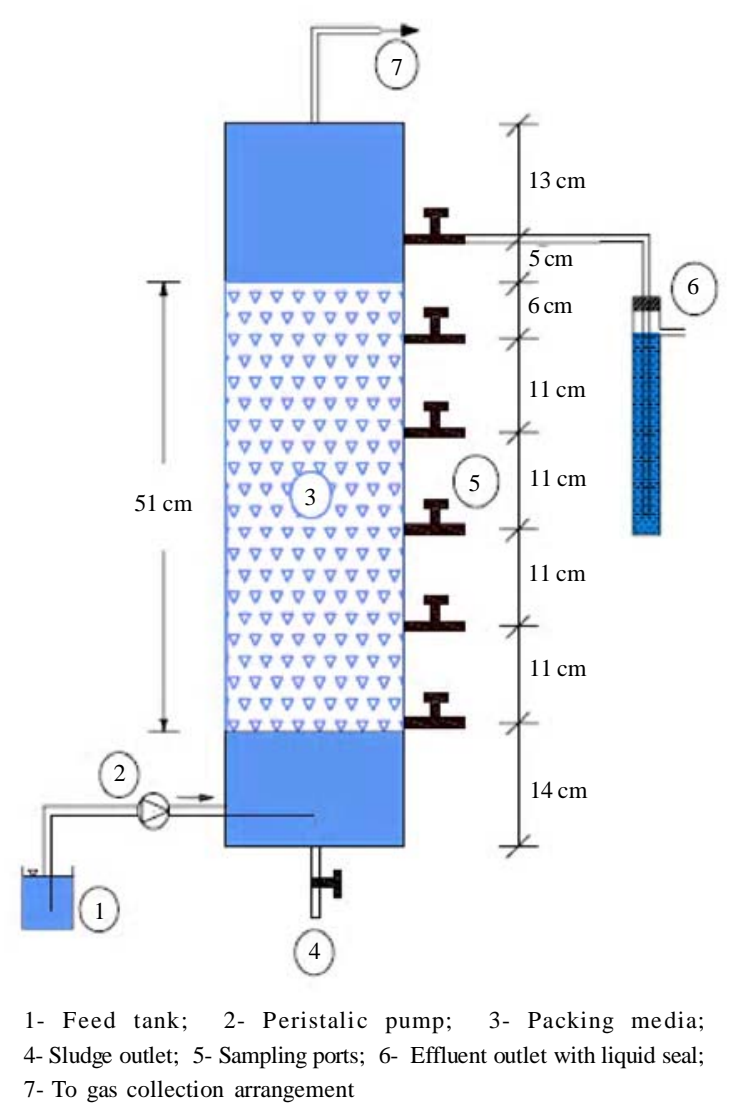

Fig.1: Schematic arrangement of upflow anaerobic filter reactor

\section{Support material}

Pleated PVC ring was selected as packing media because of its pleated surface can retain more biomass on surfaces rather than plain surfaces. The packing media had the dimensions of length, internal and external diameter $1.5,1.1$ and $1.3 \mathrm{~cm}$ respectively; porosity $98 \%$ and surface area $267 \mathrm{~m}^{2} / \mathrm{m}^{3}$.

\section{Substrate}

Poultry Slaughterhouse wastewater generated from Supreme Sugana Food Company located at Udumalpet, Tamilnadu, India was used as substrate. The wastewater was collected after a fat separator to avoid the hindrance of fat in the anaerobic digestion process. The wastewater used as feed was maintained in a refrigerator at $4{ }^{\circ} \mathrm{C}$. It was maintained in a feed reservoir and mixing was performed manually at regular interval. The substrate used for the experiment was combined slaughterhouse process wastewater. Characteristics of the wastewater are summarized in Table 1.

\section{Seed sludge}

The reactors were seeded anaerobically with a non granular sludge obtained wastewater treatment plant of the poultry slaughterhouse industry. The characteristics of seed sludge were analysed as per standard methods (APHA, 1992). The total solids, total suspended solids (TSS), volatile suspended solids (VSS), and ratio of VSS/TSS are found to be 28,000, $14400,10100 \mathrm{mg} / \mathrm{L}$ and 0.55 respectively.

Table1: Characteristics of poultry slaughterhouse wastewater

\begin{tabular}{llr}
\hline Sl. No. & \multicolumn{1}{c}{ Characteristics } & \multicolumn{1}{c}{ Values } \\
\hline 1. & $\mathrm{pH}$ & $7-7.6$ \\
2. & Color & Brownish grey \\
3. & Total Solids $(\mathrm{mg} / \mathrm{L})$ & $1400-3900$ \\
4. & Total Suspended Solids & $300-950$ \\
& $(\mathrm{mg} / \mathrm{L})$ & \\
5. & Total Volatile Solids $(\mathrm{mg} / \mathrm{L})$ & $800-1800$ \\
6. & BOD $_{5}(\mathrm{mg} / \mathrm{L})$ & $750-1890$ \\
7. & Total COD $(\mathrm{mg} / \mathrm{L})$ & $3000-4800$ \\
8. & Soluble COD $(\mathrm{mg} / \mathrm{L})$ & $1030-3000$ \\
9. & VFA $(\mathrm{mg} / \mathrm{L}$ as acetate) & $250-540$ \\
10. & Alkalinity (mg/L as CaCO & $600-1340$ \\
11. & Phosphates $(\mathrm{mg} / \mathrm{L})$ & $16-32$ \\
12. & Ammonia Nitrogen $(\mathrm{mg} / \mathrm{L})$ & $16-165$ \\
13. & TKN $(\mathrm{mg} / \mathrm{L})$ & $109-325$ \\
14. & Oil and Grease $(\mathrm{mg} / \mathrm{L})$ & $800-1385$ \\
15. & Protein $(\mathrm{mg} / \mathrm{L})$ & $580-1000$ \\
\hline
\end{tabular}




\section{Start up phase}

The reactor was started with an OLR of $0.77 \mathrm{Kg}$ $\mathrm{COD} / \mathrm{m}^{3} . \mathrm{d}$ and the initial HRT was $36 \mathrm{~h}$. Throughout the start-up period feed Total COD (TCOD) was maintained, approximately $1150 \mathrm{mg} / \mathrm{L}$ after diluting with tap water. The loading pattern was increased stepwise by reducing the HRT to 24, 16, 12, 10 and $8 \mathrm{~h}$.

\section{Treatment phase}

After the start up, the reactor was operated by varying the feed COD between 1544 and $7700 \mathrm{mg} / \mathrm{L}$ at a constant HRT of $12 \mathrm{~h}$. The performance of the reactor was monitored at regular intervals in terms of $\mathrm{pH}$, VFA, Alkalinity, COD, biogas and methane content.

\section{Chemical analysis}

Total and Soluble COD (for the soluble COD, a sample was filtered with a gas micro filter $0.45 \mu \mathrm{m}$ size), volatile fatty acids (VFA), alkalinity, volatile suspended solids (VSS), volatile solids (VS), total suspended solids (TSS), total kjeldhal nitrogen (TKN), ammonia nitrogen, phosphates, oil and grease were analyzed as per procedure detailed in standard methods (APHA, 1992). All experiments were performed in triplicate. COD of the samples were measured by dichromate reflux method. VFA were measured by distillation method. The ammonia-N was determined by direct Nesslerization method. The estimation of oil and grease was determined by partition gravimetric method.

The flow rate, $\mathrm{pH}$ and amount of biogas generated were recorded daily and other parameters TCOD, SCOD, VFA and Alkalinity were measured once in three days. The biogas composition was measured two times weekly by passing a known volume of biogas through a potassium hydroxide $(\mathrm{KOH})$ scrubber. Protein was measured by multiplying the difference between TKN and $\mathrm{NH}_{4}-\mathrm{N}$ by 6.25 (AOAC, 1984). The specific methanogenic activity (SMA) of the sludge was determined using the protocol as adopted by Isa et al., (1993) without addition of nutrients (Jawed and Tare, 1999). SMA was measured from the slope of the linear portion of cumulative methane production rate and the final VSS in the serum bottle.

\section{Scanning electron microscope (SEM) analysis}

Sample preparation for SEM included fixation of sludge granule in $6 \%$ glutaraldehyde, washed with 0.1 $\mathrm{M}$ phosphate buffer and dehydrated through a series of ethanol in distilled water (50 to $100 \%$ ). Then the samples were brought to equilibrium in each mixture for $10 \mathrm{~min}$ and finally dried by the critical-point drying method before sputter-coating with gold particles. The samples were examined in a scanning electron microscope (JOEL, JSM 840 A, Japan) at $20 \mathrm{KV}$ and photomicrographs produced at a magnifications of 8000X and $10000 \mathrm{X}$.

\section{RESULTSAND DISCUSSION}

\section{Start-up of the reactor}

The initial feeding rate was about $3.6 \mathrm{~L} / \mathrm{d}$, which corresponded to a HRT of $36 \mathrm{~h}$, this gave an initial OLR of $0.77 \mathrm{kgCOD} / \mathrm{m}^{3}$.day, and the sludge loading rate (SLR) of $0.11 \mathrm{~g}$ COD/g VSS/day. The SMA of sludge was $0.09 \mathrm{~g} \mathrm{CH}_{4} \mathrm{COD} / \mathrm{g}$ VSS.day. The OLR of $0.77 \mathrm{~kg}$ $\mathrm{COD} / \mathrm{m}^{3} /$ day was maintained for 20 days until the production of gas and another 14 days it was continued in the same loading in continuous mode to enhance the growth of microbes on the media.

Subsequently the OLR's were increased stepwise to $1.15,1.74,2.27,2.88$, and $3.43 \mathrm{~kg} \mathrm{COD} / \mathrm{m}^{3}$.day by reducing the HRT to $24,16,12,10$, 8 h respectively. The general guide line adopted, during the start-up was to increase the loading when COD removal efficiency and biogas production ( $\pm 5 \%$ ) was constant for three consecutive days. During the stepped increase of OLR, COD removal efficiencies were gradually increased. This was in general agreement with COD removal efficiencies were increased with time of operation (Saravanane et al., 2001). But, the reduction in HRT less than $12 \mathrm{~h}$ shown decreased trend in COD removal efficiencies in terms of both TCOD and SCOD. This may be due to the fact that during the short contact time between biomass and substrate the entrapment/ removal capacity was ultimately reduced (Lettinga et al., 1997). Hence the HRT was reverted back and maintained at $12 \mathrm{~h}$. The reactor took 147 days for complete start-up. The longer start-up may be attributed, due to low SMA of the sludge used for seeding of the reactors as well as it was needed much time to form the microbial growth onto the filter material. At the end of the start-up, the reactor achieved the TCOD and SCOD removal efficiencies of 70 and $79 \%$, respectively. Bio gas production was found to be 2.4 L/day with a methane content of $56 \%$.

\section{Performance of the reactor}

After achieving the start-up at an OLR of $2.27 \mathrm{~kg} /$ $\mathrm{m}^{3} /$ day the reactor was further loaded with increasing 
OLR to assess the optimum loading rate of the reactor. This was evaluated by increasing the COD concentration after fixing the optimum HRT of $12 \mathrm{~h}$ and the reactor was operated up to an OLR of $15.4 \mathrm{~kg} / \mathrm{m}^{3} /$ day. Depending on the process biodegradation the reactor took 13-18 days for attaining pseudo steady state in each loading rates. Fig. 2 depicts the variations of $\mathrm{pH}$ during the treatment.

Up to an OLR of $14.3 \mathrm{~kg} / \mathrm{m}^{3} /$ day, the outlet $\mathrm{pH}$ was varied between 7.3 and 7.8 and VFA/alkalinity ratio was in the range of $0.12-0.34$. This was well within the limit of 0.4 avoiding the system failure (Leitao, 2004). The variation of VFA and alkalinity during the treatment was shown in Fig. 3. The alkalinity ranged between 875 and $1720 \mathrm{mg} / \mathrm{L}$ as $\mathrm{CaCO}_{3}$ up to an OLR of $14.3 \mathrm{~kg} / \mathrm{m}^{3} /$ day indicated that sufficient buffering capacity was favorable inside the reactor. The $\mathrm{pH}$ of treated wastewater dropped to 6.6 when the OLR was increased to 15.4 from $14.3 \mathrm{~kg} / \mathrm{m}^{3} /$ day and subsequently the ratio of VFA/alkalinity reached beyond the failure limit. The COD removal efficiencies during the treatment of poultry slaughterhouse wastewater in UAF are shown in Fig. 4.

It is evident from the Fig. 4, that increase in loading rate has shown gradual increase in removal efficiency up to an OLR of $10.05 \mathrm{~kg} / \mathrm{m}^{3} /$ day and substrate removal

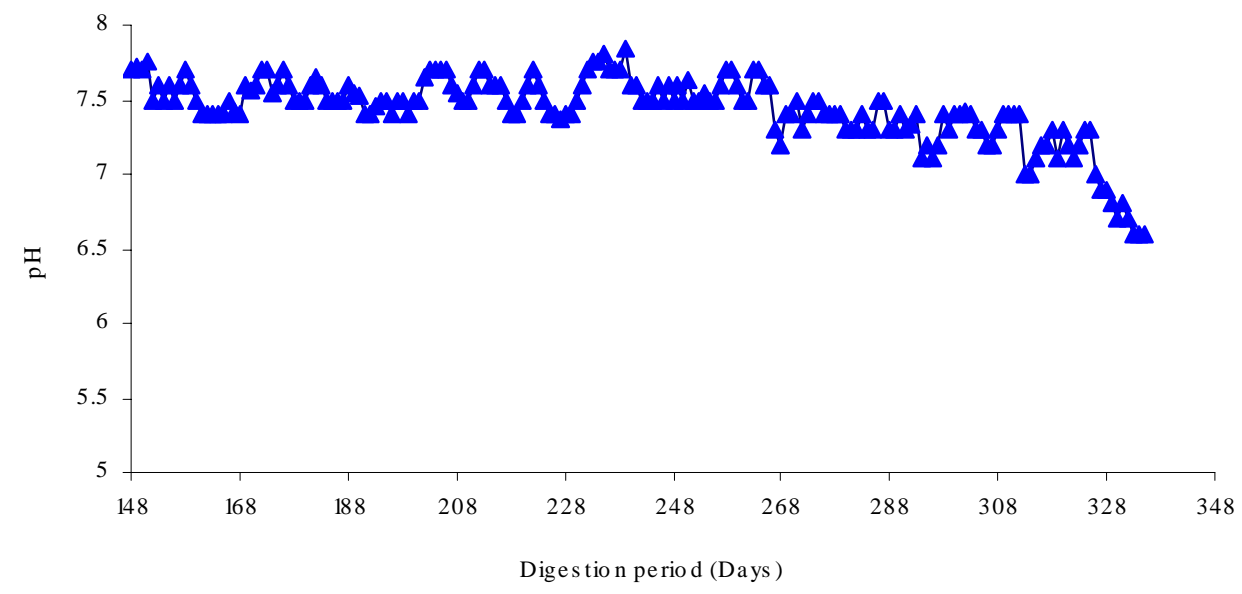

Fig. 2: Variations of $\mathrm{pH}$ during the treatment of poultry slaughterhouse wastewater in UAF

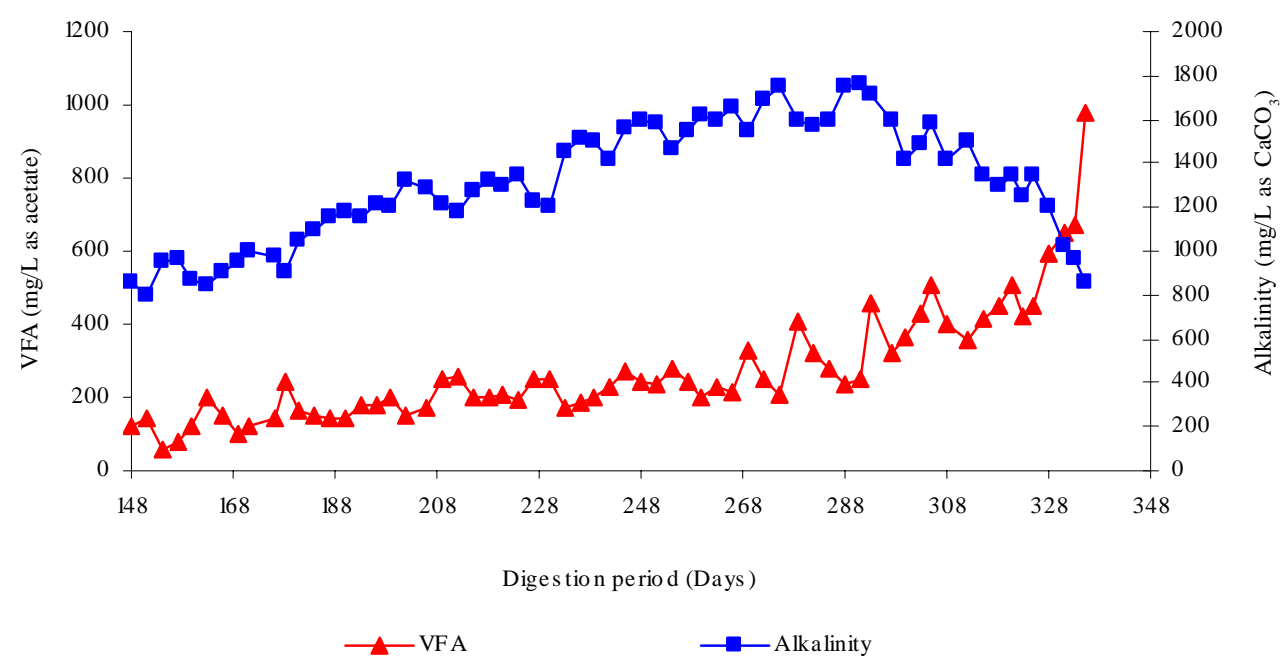

Fig. 3: Variations of VFA and alkalinity during the treatment of poultry slaughterhouse wastewater in UAF 


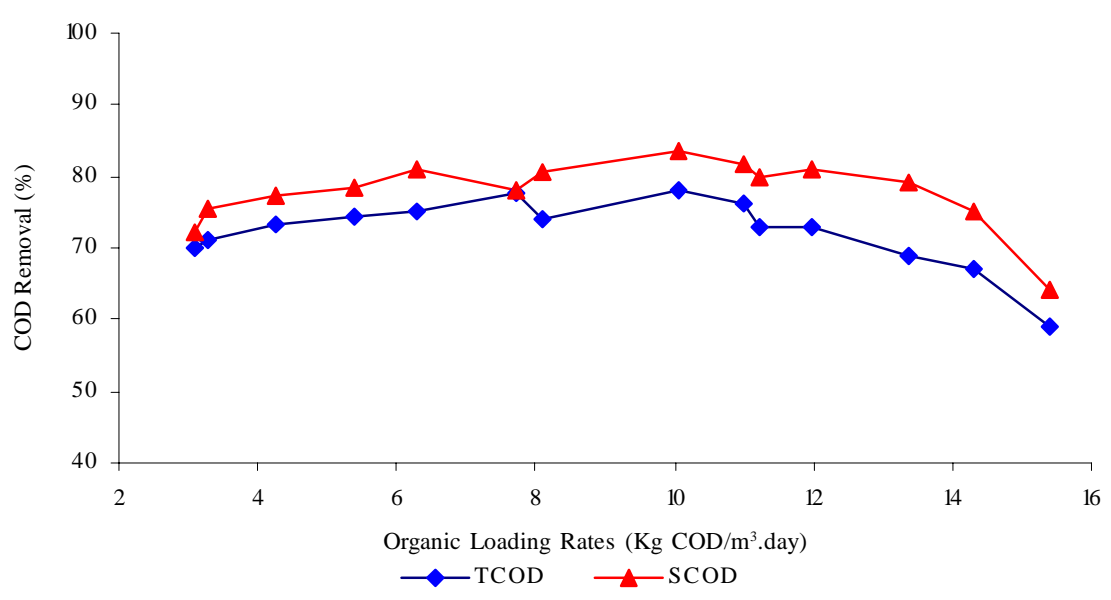

Fig. 4: Total COD and soluble COD removal during the treatment of poultry slaughterhouse wastewater in UAF

rate reduced beyond this OLR. Up to an OLR of 7.73 $\mathrm{kg} / \mathrm{m} 3 /$ day the feed was introduced without fat wastewater (i.e by taking the sample after fat separation unit) but beyond this loading the substrate consisted of fat wastewater. This procedure was adopted to increase the COD concentration. At an OLR of $8.1 \mathrm{~kg} /$ $\mathrm{m}^{3} /$ day there was a sudden decrease in total COD removal efficiency to a level of $74.20 \%$ due to introduction of fat wastewater. However, it was increased to $78 \%$ at an OLR of $10.05 \mathrm{~kg} / \mathrm{m}^{3} /$ day after stabilization of reactor operation. At an OLR of 11.98 $\mathrm{kg} / \mathrm{m}^{3} /$ day the reduced removal efficiency of $73 \%$ was observed. Further loading of reactor did not show higher removal efficiency and SS content increased in the effluent. At an OLR of $14.3 \mathrm{~kg} / \mathrm{m}^{3} /$ day increased SS content in the effluent reduced the SS removal to $54 \%$. This condition forced to shut down the reactor for $24 \mathrm{~h}$ and again it was restarted. Then the reactor was resumed in normal operation for 3 days but sludge washout continued and the efficiency reduced to all time low of 59 and $64 \%$ in terms of TCOD and SCOD respectively, at an OLR of $15.4 \mathrm{~kg} \mathrm{COD} / \mathrm{m}^{3} /$ day. This could be due to that high influent fat levels contributed to loss of sludge at higher loading rates (Batstone et al., 2004) as well as potential media clogging and channeling of reactor reduced the removal efficiencies (Jhung and Choi, 1995). It was observed that the reactor can be operated up to an OLR of $10 \mathrm{~kg} / \mathrm{m}^{3} /$ day without system failure. This similar optimum OLR of $10 \mathrm{~kg} / \mathrm{m}^{3} /$ day was achieved when anaerobic fixed film reactor (AFFR) treating pharmaceutical wastewater (Gangagni et al., 2005). At an OLR of $10 \mathrm{~kg} / \mathrm{m}^{3} /$ day, optimum removal efficiencies of TCOD and SCOD removal were 78 and $83.5 \%$, respectively.

\section{Biogas production and Methane yield}

It is evident from the Fig. 5 that the gas production increased while increasing OLR and reached the maximum of $20.3 \mathrm{~L} / \mathrm{d}$ at an OLR of $11.98 \mathrm{~kg} / \mathrm{m}^{3} /$ day. The biogas was found to have 46-56 \% of methane $\left(\mathrm{CH}_{4}\right)$ and substantial amount of carbon di-oxide $\left(\mathrm{CO}_{2}\right)$ and traces of nitrogen $\left(\mathrm{N}_{2}\right)$ and hydrogen sulfide $\left(\mathrm{H}_{2} \mathrm{~S}\right)$. Fig. 6 depicts variations of methane yield as a function of OLR at steady state conditions. After the introduction of fat wastewater at an OLR of $8.1 \mathrm{~kg} / \mathrm{m}^{3} /$ day the methane yield was reduced to $0.25 \mathrm{~m}^{3} \mathrm{CH}_{4} / \mathrm{kg}$ COD.day due to the poor activity of sludge and limitations of mass transfer between substrate and biomass (Alphenaar, 1994). Biogas production rate was $18.4 \mathrm{~L} /$ day at an OLR of $10 \mathrm{~kg} / \mathrm{m}^{3} /$ day with methane yield of $0.24 \mathrm{~m}^{3} \mathrm{CH}_{4} / \mathrm{kg}$ COD.day.

It may be noted that though the removal efficiency was in higher range at an OLR of $10.05 \mathrm{~kg} / \mathrm{m}^{3} /$ day, the lower methane content indicating that at higher OLR the methanogenic activity was reduced due to the inhibition of fats and SS present in the wastewater. Beyond the OLR of $11.98 \mathrm{~kg} \mathrm{COD} / \mathrm{m} 3 . \mathrm{d}$ the biogas production started to reduce and finally it was reached to all time low of $14.2 \mathrm{~L} / \mathrm{d}$ at an OLR of $15.4 \mathrm{~kg} \mathrm{COD/}$ m3.d. The methane content also reduced to $42 \%$ at the end of the experiment. Khageshan and Govindan (1995) reported that beyond an OLR of $11.64 \mathrm{~kg} \mathrm{COD} / \mathrm{m}^{3} / \mathrm{d}$, 


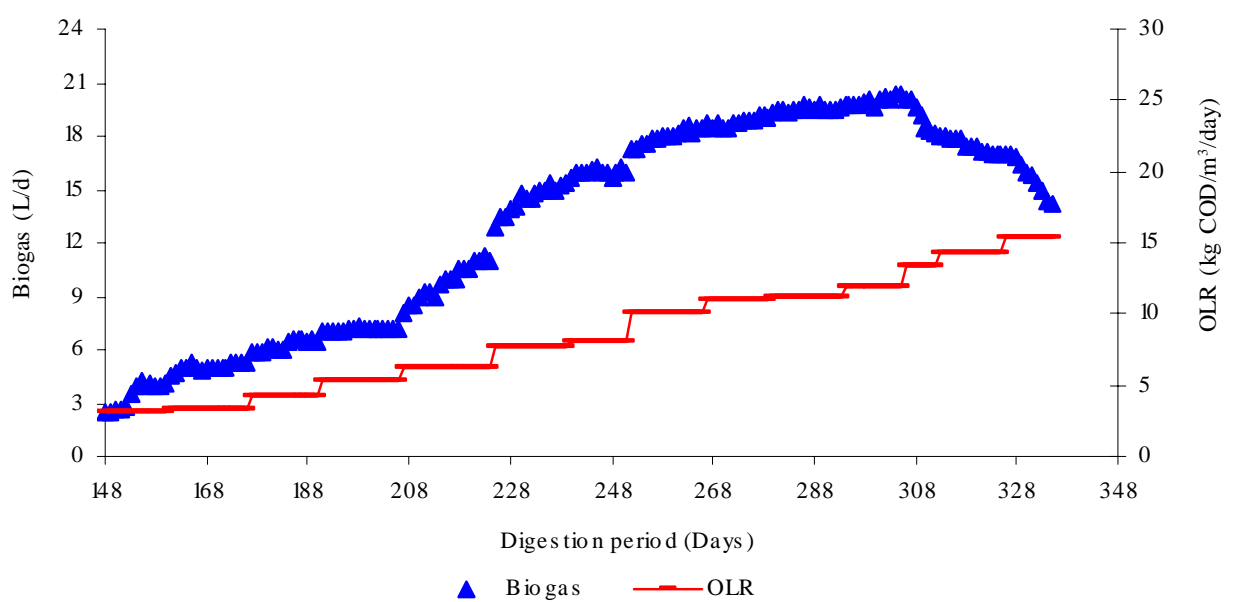

Fig. 5: Organic loading pattern and biogas production during the treatment of poultry slaughterhouse wastewater in UAF

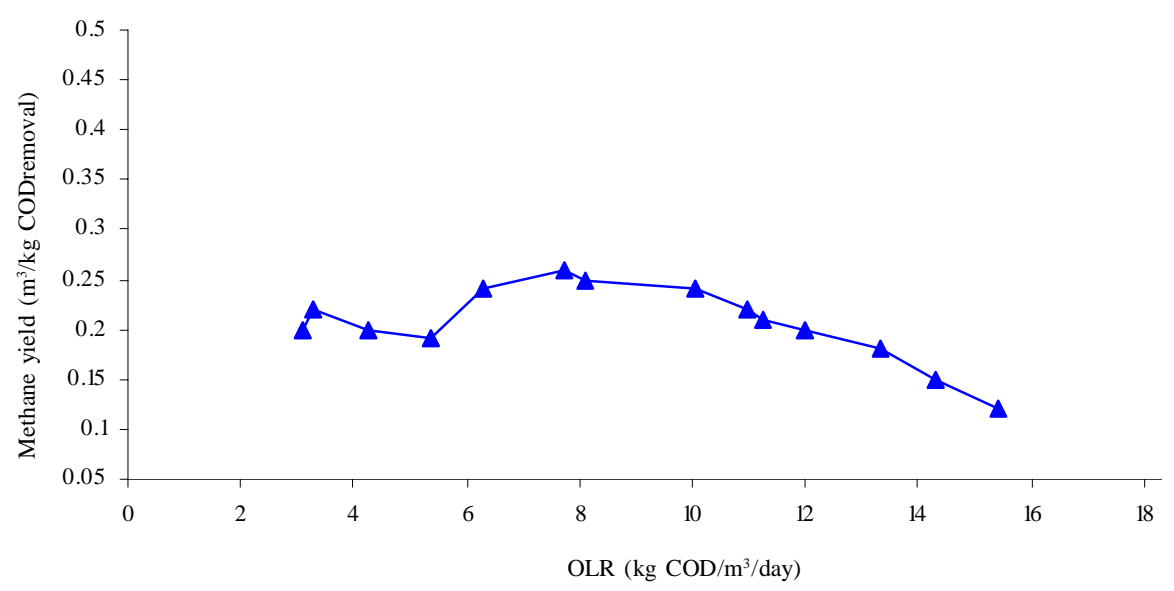

Fig. 6: Variations of methane yield as a function of OLR at steady state during the treatment

gas production is reduced during the treatment of synthetic sago wastewater using anaerobic filter with basalt stone chips as filter medium.

\section{Granule formation}

The small sizes of sludge granules of sizes 1-2 mm were observed at bottom portion of the reactor (bottom two ports). Less than $1 \mathrm{~mm}$ of granules was observed at mid depth of the reactor. This had proven that the possibility of granules may be occurred in attached growth in between the intersices of the packing media (Tilche and Vieira, 1991). The soluble
COD removal was high throughout the study which was due to the reason the small granules present between the packing media had a special effect of removing the soluble COD in higher range (Elmitwalli et al., 1999). The higher removal rates of SCOD could be explained that when substrate reached the biomass it will diffuse into the surfaces of the attached or granulated solids. Also, the fact that the substrate transport limitation was less in small granules, compared to attached biomass which had higher mass transfer limitation due to higher thickness (Alphenaar, 1994). 


\section{SEM Observation}

Biomass samples were collected from the reactor and analysed for microbial diversity. SEM analysis revealed that Methanosarcina cells are abundance in attached microbial growth (Fig.7 a). The similar observation was concluded by Picanco et al., (2001) when treating synthetic wastewater containing proteins, lipids and carbohydrates. The sludge granules were composed of clumps of Methanosarcina clustered with very less Methanosaeta fibre of granules (Fig.7 b and c). However, the predominant types were Methanosarcina

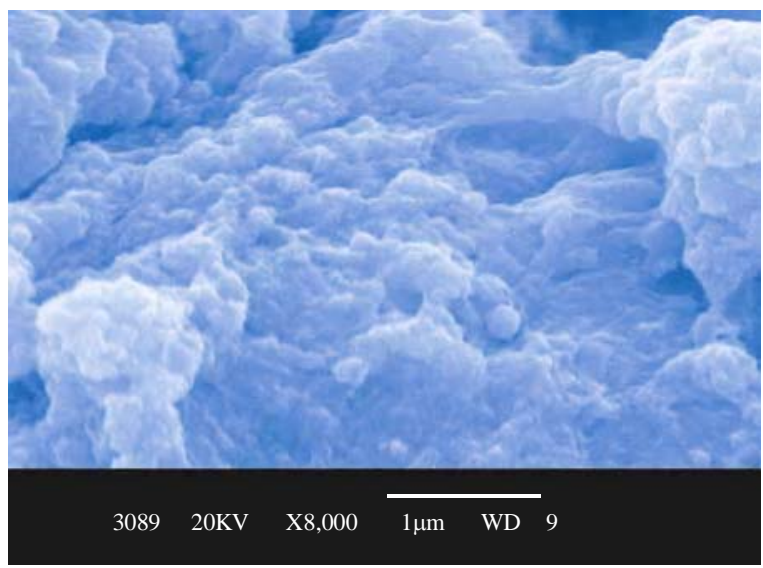

(a) -like cells. It is known that Methanosaeta spp. is homoacetogenic bacteria which utilize only acetate as sole substrate because at low acetate concentrations Methanosaeta spp. had higher substrate affinity to acetate. Methanosarcina spp. utilize acetate, formate, $\mathrm{H}_{2}, \mathrm{CO}_{2}$ and methanol as for their growth and maintenance and also at high acetate concentrations Methanosarcina Spp. had higher substrate affinity to acetate (Zinder, 1993). This was evidenced by the growth that Methanosarcina spp. dominated Methanosaeta spp. since the acetate concentration (980 $\mathrm{mg} / \mathrm{L}$ as acetate) was more in the reactor.

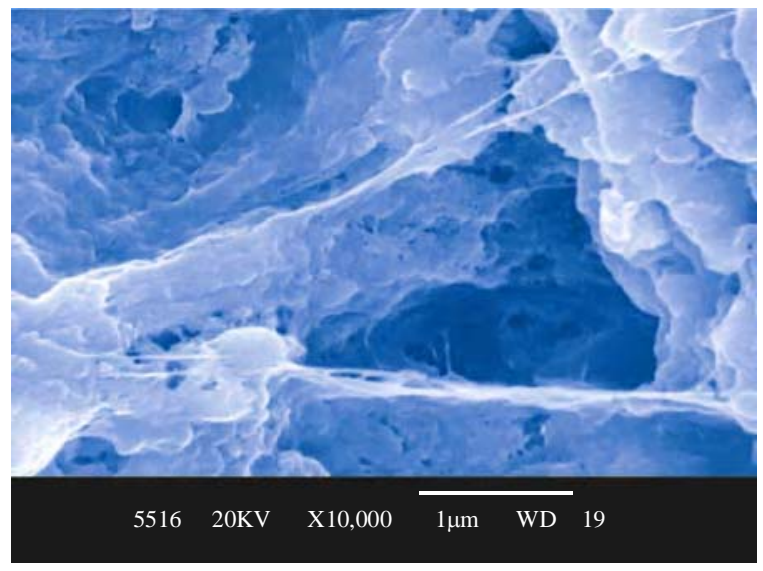

(b)

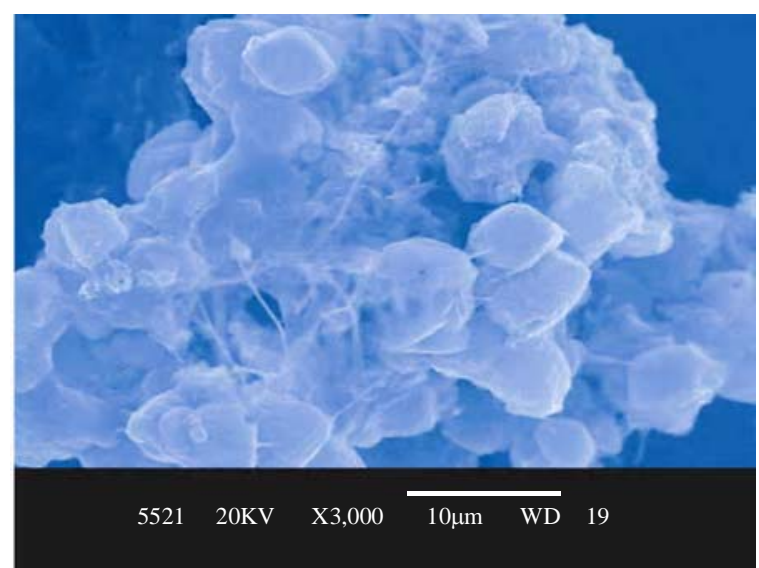

(c)

Fig. 7: SEM picture of Colony of Methanosarcina -like cells on attached growth (a), clumps of Methanosarcina clustered with very less Methanosaeta fibre of granules (b) and (c) 


\section{CONCLUSION}

The start-up of UAF was completed at the end of 147 days by using non-granular sludge. Though the upflow velocities are low, the maximum TCOD and SCOD removal efficiencies of $78 \%$ and $83.5 \%$ were observed at an OLR of $10.05 \mathrm{~kg} / \mathrm{m}^{3} /$ day. The average methane content varied between 46-56 \% and methane yield at maximum removal efficiency was $0.24 \mathrm{~m}^{3} \mathrm{CH} 4$ / $\mathrm{kg} \mathrm{COD}_{\text {removed }}$. After the continuous introduction of fat wastewater the removal efficiency was considerably dropped due to the inhibition of fat and SS, which caused the substrate transport limitation, beyond the OLR of $10.98 \mathrm{~kg} / \mathrm{m}^{3} /$ day. Hence it is recommended that the poultry slaughterhouse wastewater could be treated in anaerobic filter keeping the fat content at optimum level. However, further studies are required at a wider range of fat concentration, to find out the optimum fat level to maintain the reactor without 'souring'. Though the removal efficiency reduced to $67 \%$ at an OLR of $14.3 \mathrm{~kg} / \mathrm{m}^{3} /$ day, the $\mathrm{pH}$ maintained was 7.3 which showed the sufficient buffering capacity was prevailed up to this OLR. The SEM images shown that sludge granules are composed of clumps of Methanosarcina clustered with very less Methanosaeta fibre of granules. All the above results indicated that sufficient buffering capacity with active microbial population inside the reactor was enhanced the performance of reactor, which evidenced that the poultry slaughterhouse wastewater can be treated using anaerobic filter reactor under low upflow velocity.

\section{ACKNOWLEDGEMENTS}

The authors wish to acknowledge the Supreme Suguna Foods Company Ltd., (SSFCL), Udumalpet and Post Graduate students of Govt. College of Technology, Coimbatore, Tamilnadu, India, for their support in carrying out the experimental work.

\section{REFERENCES}

Alphenaar, A., (1994). Anaerobic granular sludge: characterization and factors affecting its functioning. Ph.D. thesis Wageningen Agricultural University. The Netherlands.

AOAC, (1984). Official methods of analysis of the association of official analytical chemists. Arlington, VA: Association official Analytical chemists.

APHA, (1992). Standard methods for examination of water and wastewater. APHA, AWWA, AWWA, WPCF. Washington DC.

Banu, J. R.; Kaliappan, S.; Yeom, I. T., (2007). Treatment of domestic wastewater using upflow anaerobic sludge blanket reactor. Int. J. Environ. Sci. Tech., 4 (3), 363370 (8 pages).
Batstone, D. J.; Keller, J.; Blackall, L. L., (2004). The influence of substarte kinetics on the microbial community structure in granular anaerobic biomass. Water Res., 38 (6), 13901404 (15 pages).

Behera, S. K.; Rene, E. R.; Murthy, D. V. S., (2007). Performance of up-flow anoxic bioreactor for wastewater treatment. Int. J. Environ. Sci. Tech., 4 (2), 247-252 (6 pages).

Bicheldey; T. K.; Latushkina, E., (2010). Biogass emission prognosis at the landfills. Int. J. Environ. Sci. Tech., 7 (4), 623-628 (6 pages).

Borja, R.; Banks, C. J., (1995). Comparison of an anaerobic filter and anaerobic fluidized bed reactor treating palm oil mill effluent. Process Biochem., 30 (6), 511-521 (11 pages).

case study of Indian poultry sector, phase I project report, India.

Del pozo, R.; Diez, V.; Beltran, S., (2000). Anaerobic pretreatment of slaughterhouse wastewater using fixed-film reactors. Biores. Tech., 71 (2), 143-149 (7 pages).

Elmitwalli, T. A.; Zandvoort, M.; Zeeman, G.; Bruning, H.; Lettinga, G., (1999). Low temperature treatment of domestic sewage in upflow anaerobic sludge blanket and anaerobic hybrid reactors. Water Sci. Tech., 39 (5), 177-185 (9 pages).

Gangagni Rao, A.; Venkata Naidu, G.; Krishna Prasad, K.; Chandrasekhar Rao, N.; Venkata Mohan, S.; Annapurna Jetty; Sharma, P. N., (2005). Anaerobic treatment of wastewater with high suspended solids from a bulk drug industry using fixed film reactor (AFFR). Biores. Tech., 96 (1), 87-93 (7 pages).

Ghangrekar, M. M.; Kahalekar, U. J.; Takalkar, S. V., (2003). Design of upflow anaerobic sludge blanket reactor for treatment of organic wastewaters. Indian J. Environ. Health, 45 (2), 121-132 (12 pages).

Grotenhuis, J. T. C.; Kissel, J. C.; Plugge, C. M.; Stams, A. J. M.; Zehnder, A. J. B., (1991). Role of substrate concentration in particle size distribution of methanogenic granular sludge in UASB reactors. Water Res., 25 (1), 21-27 (7 pages).

Guerrero, L.; Omil, F.; Mendez, R.; Lema, J. M., (1997). Treatment of saline wastewaters from fish meal factories in an anaerobic filter under extreme ammonia concentrations. Biores. Tech., 61 (1), 69-78 (10 pages).

Hulshoff Pol, L. W.; de Zeeuw, W. J.; Velzeboer, C. T. M.; Lettinga, G., (1983). Granulation in UASB recators. Water Sci. Tech., 15 (8/9), 291-304 (14 pages).

Igwe, J. C.; Abia, A. A.; Ibeh, C. A., (2008). Adsorption kinetics and intraparticulate diffusivities of $\mathrm{Hg}$, $\mathrm{As}$ and $\mathrm{Pb}$ ions on unmodified and thiolated coconut fiber. Int. J. Environ. Sci. Tech., 5 (1), 83-92 (10 pages).

Isa, M. H.; Farooqi, I. H.; Siddiqi, R. H., (1993). Methanogenic activity test for study of anaerobic processes. Indian J. Environ. Health, 35 (1), 1-8 (8 pages).

Jawed, M.; Tare, V., (1997). Comparative evaluation of anaerobic packed bed and sludge blanket reactors. Proceedings of the 8th International conference on anaerobic digestion (AD_97), Sendai, Japan, Vol. 3, 169-172 (4 pages).

Jawed, M.; Tare, V., (1999). Microbial composition assessment of anaerobic biomass through methanogenic activity tests. Water SA., 25 (3), 345-350 (6 pages).

Jawed, M.; Tare, V. (2000). Post-mortem examination and analysis of anaerobic filters. Biores. Tech., 72 (1), 75-84 (10 pages). 
Jhung, J. K.; Choi, E., (1995). A comparative study of UASB and anaerobic fixed film recators with development of sludge granulation. Water Res., 29 (1), 271-277 (7 pages).

Juang, D. F.; Chiou, L. J., (2007). Microbial population structures in activated sludge before and after the application of synthetic polymer. Int. J. Environ. Sci. Tech., 4 (1), 119-125 (7 pages).

Karapidakis, E. S; Tsave, A. A; Soupios, P, M ; Katsigiannis, Y. A.,(2010). Energy efficiency and environmental impact of biogas utilization in landfills. Int. J. Environ. Sci. Tech., 7 (3), 599-608 (10 pages)

Khageshan, P.; Govindan, V. S., (1995). Anaerobic filter for treatment of sago wastewater. Proceedings of 4 th national symposium on Environment, Chennai, India, 248-252 (5 pages).

Kroyer, G., (1991). Food processing wastes, in: Bio conversion of waste materials to industrial products. A. M. Martin (Ed.), Elsevier applied science, Newyork, 293-311 (19 pages).

Leitao, R. C., (2004). Robustness of UASB reactors treating sewage under tropical conditions. Ph.D. thesis, Wageningen University, Wageningen, The Netherlands.

Lettinga, G.; Field, J.; van Lier Zeeman, G.; Hulshoff Pol, L. W., (1997). Advanced anaerobic wastewater treatment in the near future. Water Sci. Tech., 35 (10), 5-12 (8 pages).

Liu, R. R.; Tian, Q.; Yang, B.; Chen, J., (2010). Hybrid anaerobic baffled reactor for treatment of desizing wastewater. Int. J. Environ. Sci. Tech., 7 (1), 111-118 (8 pages).

Mehta, R.; Nambiar, R. G., (2002). Live stock industrialization trade and social-health environment impact in developing countries. A

Nwuche, C. O.; Ugoji, E. O., (2008). Effects of heavy metal pollution on the soil microbial activity. Int. J. Environ. Sci. Tech., 5 (3), 409-414 (6 pages).

Okoli, I. C; Nweke, C. U; Okoli, C. G; Opara, M. N., (2006). Assessment of the mycoflora of commercial poultry feeds sold in the humid tropical environment of Imo State, Nigeria. Int. J. Environ. Sci. Tech., 3 (1), 9-14 (6 pages).
Picanco, A. P.; Vallero, M. V. G.; Gianotti, E. P.; Zaiat.; Blundi, C. E., (2001). Influence of porosity and composition of supports on the methanogenic biofilm characteristics developed in a fixed bed reactor. Water Sci. Tech., 44 (4), 197-204 (8 pages).

Ruiz, I.; Veiga, M. C.; de Santiago, P.; Blázquez., (1997). Treatment of slaughterhouse wastewater in a UASB reactor and an anaerobic filter. Biores. Tech., 60 (3), 251-258 (8 pages).

Saravanane, R.; Murthy, D. V. S.; Krishnaiah., (2001). Anaerobic treatment and biogas recovery for sago wastewater management using a fluidized bed reactor. Water Sci. Tech., 44 (6), 141-147 (7 pages).

Shah, B. A; Shah, A. V.; Sigh, R. R ., (2009). Sorption isotherms and kinetics of chromium uptake from wastewater using natural sorbent material. Int. J. Environ. Sci. Tech., 6 (1),7790 (14 pages).

Tay, J.; Show, K., (1998). Media-Induced hydraulic behaviour and performance of upflow filters. J. Environ. Eng., 124 (8), 720-729 (10 pages).

Tay, J.; Yan, Y., (1996). Influence of substrate concentration on microbial selection and granulation during start-up of upflow anaerobic sludge blanket reactors. Water Env. Res., 68 (7), 1140-1150 (11 pages).

Thirumurthi, D., (1988). Effects of mixing velocity in anaerobic fixed film reactors. Water Res., 22 (4), 517-523 (7 pages).

Tilche, A.; Vieira, S. M. M., (1991). Discussion report on reactor design of anaerobic filters and sludge bed reactors. Water Sci. Tech., 24 (8), 193-206 (14 pages).

Tritt, W. P., (1992). The anaerobic treatment of slaughterhouse wastewater in fixed-bed reactors. Biores. Tech., 41 (3), 201207 (7 pages).

Zinder, S. H., (1993). Physiological ecology of methanogens. In: J.G. Ferry, editor. Methanogenesis: ecology, biochemistry and genetics. Newyork: Chapman and Hall.

\section{AUTHOR (S) BIOSKETCHES}

Rajakumar, R., M.E., Ph.D., DIS., is a Deputy Manager (Environment) in the Engine Division, Hindustan Aeronautics Ltd., Banaglore-

560 093, Karnataka, India. Email: rrajakumar_78@yahoo.com

Meenambal, T., M.E., Ph.D., is an Assistant Professor in the Department of Civil Engineering, Government College of Technology, Anna University, Coimbatore-641 013, TamilNadu, India. Email: tmeenambal_gct@yahoo.co.in

Rajesh Banu, J., M.Sc., Ph.D., is an Assistant Professor in the Department of Civil Engineering, Anna University, Tirunelveli-627 007 , TamilNadu, India. Email: rajeshces@gmail.com

Yeom I. T., is a professor in the Deptartment of Civil and Environmental Engineering, SungKyunKwan University, Suwon-Si, South Korea. Email: yeom@skku.edu 